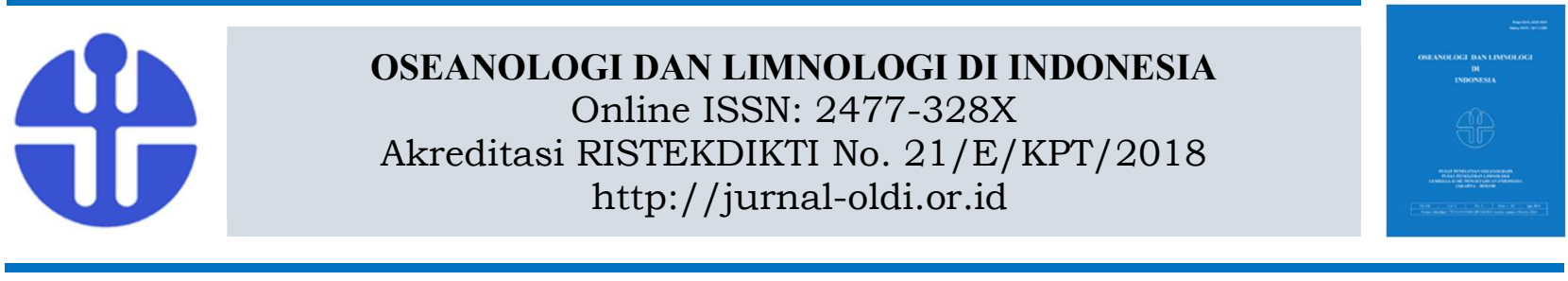

\title{
Estimasi Stok Karbon pada Biomassa Lamun di Pulau Semak Daun, Kepulauan Seribu
}

\author{
Jessica V. Gunawan', Maxi Parengkuan'1, A'an J. Wahyudi² dan Firman Zulpikar² \\ ${ }^{1}$ Jurusan Teknik Lingkungan, Fakultas Teknik, Universitas Surya, Grand Serpong Mall Lt. 1 Unit F8 \& F9, \\ Jl. M.H. Thamrin Km 2.7, Tangerang; Banten, Indonesia \\ ${ }^{2}$ Pusat Penelitian Oseanografi LIPI, Jl. Pasir Putih I, Ancol Timur, Jakarta Utara, DKI Jakarta, Indonesia \\ Email: meiying18jessica@gmail.com
}

Submitted 26 November 2018. Reviewed 27 February 2019. Accepted 18 July 2019.

DOI: 10.14203/oldi.2019.v4i2.229

\begin{abstract}
ABSTRAK
Ekosistem lamun memiliki peran penting dalam pertahanan ekosistem pesisir. Ekosistem lamun juga dapat menyerap karbon dan menyimpannya sebagai materi organik dalam waktu lama. Namun, aktivitas antropogenik di daerah pesisir memberikan tekanan lingkungan kepada ekosistem lamun. Penelitian ini dilakukan untuk mengkaji stok karbon biomassa lamun di Pulau Semak Daun untuk menilai potensi ekosistem padang lamun di area ini dalam penyerapan karbon. Pengamatan dilakukan di ekosistem lamun untuk mendapatkan nilai kerapatan, frekuensi kemunculan, kualitas air serta aktivitas antropogenik di sekitar ekosistem lamun. Pengambilan sampel dilakukan untuk mendapatkan data biomassa dan stok karbon lamun. Stok karbon dihitung dengan metode pengabuan, kemudian dikombinasikan dengan nilai kerapatan untuk mengetahui potensi stok karbon pada keseluruhan area padang lamun. Spesies lamun yang ditemukan di perairan Pulau Semak Daun adalah Halophila ovalis, Thalassia hemprichii, Cymodocea rotundata, Syringodium isoetifolium, dan Halodule uninervis. Luas ekosistem lamun Pulau Semak Daun sebesar 9,1 ha dengan nilai stok karbonnya sebesar 1,84 ton $\mathrm{C}$ atau setara dengan 6,76 ton $\mathrm{CO}_{2}$. Stok karbon sebesar $52 \%$ berasal dari biomassa lamun bagian bawah substrat dan $48 \%$ dari biomassa lamun bagian atas substrat.
\end{abstract}

Kata kunci: lamun, stok karbon, biomassa, Semak Daun, Kepulauan Seribu

\section{ABSTRACT}

Carbon Stock Estimation in Seagrass Biomass on Semak Daun Island, Thousand Islands. Seagrass ecosystem has a vital role in protecting the coastal ecosystem. It can also sequester and store carbon as an organic material (blue carbon) for a long time. However, anthropogenic activities in coastal areas give environmental stress on the seagrass ecosystem. This research was conducted to assess the carbon stock of seagrass biomass in Semak Daun Island in order to evaluate the potential of the seagrass meadows in sequestering carbon. Sampling and observation were held in the seagrass ecosystem to obtain seagrass density, biomass, frequency of occurrence, water quality, and anthropogenic activity. Carbon stock was calculated by the loss of ignition (LOI) method, and combined with density to determine the total carbon stock in the whole area of seagrass meadows. Seagrass species in Semak Daun Island consist of Halophila ovalis, Thalassia hemprichii, Cymodocea rotundata, Syringodium isoetifolium, and Halodule uninervis. The coverage area of seagrass in Semak Daun Island was 9.1 ha with carbon stock value of 1.84 ton C or equivalent to 6.76 ton $\mathrm{CO}_{2}$. Fifty two percent of the carbon stock was originated from the below-ground biomass and $48 \%$ from the above-ground biomass.

Keywords: seagrass, carbon stock, biomass, Semak Daun, Thousand Island 


\section{Pendahuluan}

Revolusi industri pada abad ke-18 menyebabkan kadar $\mathrm{CO}_{2}$ di atmosfer terus bertambah dan menyebabkan kenaikan suhu global hingga $0,9^{\circ} \mathrm{C}$ pada tahun 2017 dibandingkan tahun 1880 (NASA GISS, 2018). Kenaikan suhu global memberikan dampak berupa perubahan suhu air laut, kenaikan muka air laut, naiknya $\mathrm{pH}$ air laut, gangguan ekologis, dan perubahan iklim. Terjadinya perubahan suhu permukaan dan penurunan $\mathrm{pH}$ air laut menyebabkan kerusakan pada ekosistem pesisir, seperti matinya terumbu karang, terhambatnya pertumbuhan bakau, menurunnya kondisi padang lamun (seagrass meadows), hingga berkurangnya produktivitas perairan (Putuhena, 2011).

Ekosistem pesisir memiliki peranan penting dalam pertahanan pesisir yaitu sebagai pemecah gelombang dan arus, pelindung pantai dari abrasi dan sebagai pereduksi bahan pencemar (BPLH Daerah Provinsi DKI Jakarta, 2010). Hutan bakau dan padang lamun yang termasuk dalam ekosistem pesisir memiliki kemampuan untuk menyimpan karbon (carbon storage) (Howard et al., 2014). Ekosistem lamun dapat menyimpan stok karbon dalam jumlah besar karena didukung oleh kondisi substrat yang jenuh dengan air dan juga kemampuan lamun dalam menangkap sedimen. Kondisi substrat yang selalu jenuh air menciptakan keadaan yang anoksik yang tidak mendukung reaksi pelepasan karbon, sehingga karbon dapat tersimpan pada ekosistem lamun dalam waktu yang lama (Howard et al., 2014).

Padang lamun memiliki peran penting dalam mengurangi emisi karbon pada atmosfer dan laut. Namun, aktivitas antropogenik di daerah pesisir memberikan tekanan lingkungan kepada ekosistem lamun, salah satunya adalah kegiatan pariwisata. Kegiatan ini menimbulkan kerusakan fisik dan limbah. Akibatnya, kerapatan lamun menjadi berkurang dan kemampuan ekosistem lamun dalam menyerap karbon juga menurun (Feryatun et al., 2012). Kemampuan padang lamun dalam mengurangi emisi $\mathrm{CO}_{2}$ dapat diketahui dengan menghitung potensi cadangan karbon ekosistem lamun.
Salah satu pulau yang menjadi destinasi wisata di Kepulauan Seribu adalah Pulau Semak Daun. Rata-rata kunjungan di Pulau Semak Daun sebesar 166 orang/hari. Aktivitas yang biasanya dilakukan para pengunjung di Pulau Semak Daun adalah aktivitas rekreasi berupa snorkeling/berenang, menangkap biota laut, memancing, berjalan di perairan dangkal, dan berkemah. Selain itu, limbah domestik yang dihasilkan wisatawan juga memiliki potensi untuk menurunkan stok karbon Pulau Semak Daun. Oleh karena itu, perlu dilakukan penelitian tentang stok karbon pada biomassa lamun di Pulau Semak Daun, Kepulauan Seribu. Dalam penelitian ini, stok karbon yang dilihat adalah yang berasal dari biomassa lamun yang terbagi menjadi dua kelompok, yaitu bagian atas susbtrat (aboveground biomass (Abg)) yang terdiri dari daun, batang dan tangkai dan biomassa di bawah substrat (belowground biomass (Blg)) yang terdiri dari akar dan rizoma (Howard et al., 2014).

\section{Metodologi}

\section{Lokasi dan Waktu Pengambilan Sampel}

Penelitian dilakukan di Pulau Semak Daun yang termasuk Kelurahan Pulau Panggang, Kecamatan Kepulauan Seribu Utara, Kabupaten Kepulauan Seribu, DKI Jakarta, dengan letak geografis berada pada $5^{\circ} 43^{\prime} 46^{\prime \prime}-5^{\circ} 43^{\prime} 49.12$ ” LS dan 106 34'12,98" - 106 34'19,38" BT (Gambar 1). Pulau ini memiliki luas sebesar 0,75 ha (BPLH Daerah Provinsi DKI Jakarta, 2015) dan berfungsi sebagai camping ground, pariwisata dan tidak terdapat pemukiman. Menurut penelitian yang telah dilakukan oleh Muliawaty et al. (2012) pada tahun 2010, spesies lamun yang ditemukan di Pulau Semak Daun adalah Cymodocea rotundata, Thalassia hemprichii, Halodule uninervis, dan Halophila ovalis.

Pengamatan dilakukan pada 21 April dan 19 Mei 2018 di ekosistem lamun Pulau Semak Daun untuk mendapatkan nilai kerapatan, frekuensi kemunculan, dan kualitas air. Pengolahan sampel untuk mendapatkan nilai stok karbon dilakukan di Laboratorium Teknik Lingkungan Surya University dan Laboratorium Biogeokimia Pusat Penelitian Oseanografi - Lembaga Ilmu Pengetahuan Indonesia. 


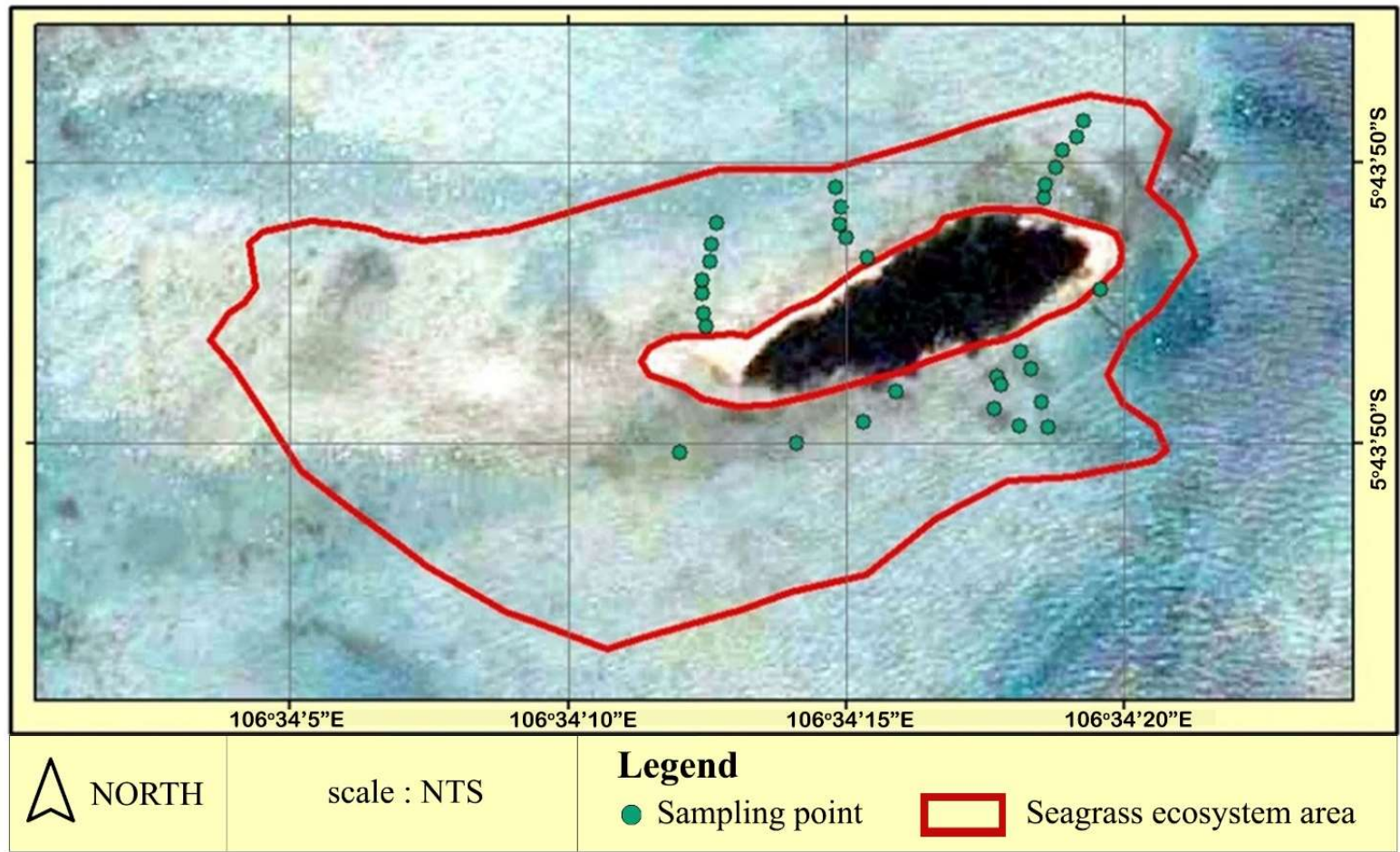

Gambar 1. Lokasi pengambilan sampel dan luas ekosistem padang lamun di Pulau Semak Daun, Kepulauan Seribu.

Figure 1. Sampling location and seagrass ecosystem area at Semak Daun Island, Kepulauan Seribu (Note: Basic map from@2018 Google Earth Pro).

\section{Pengambilan Sampel}

Pemilihan stasiun untuk pembuatan transek dilakukan secara purposive. Pembuatan transek pada stasiun 1 dilakukan sejajar garis pantai dengan menggunakan line transect dengan jarak antar transeknya $100 \mathrm{~m}$. Pada tiap transek diletakan plot berukuran $1 \mathrm{~m}$ x $1 \mathrm{~m}$ (Howard et al., 2014) dengan jarak antar plotnya sejauh $10 \mathrm{~m}$. Tiap plot dibagi menjadi sembilan subplot yang pada lima subplot tertentu (Gambar 2) dihitung jumlah individu lamun berdasarkan spesiesnya. Pada stasiun 2 menggunakan purposive sampling karena letak pertumbuhan lamun yang berbentuk kolonikoloni tertentu dan tidak merata. Metode sampling yang digunakan disesuaikan dengan bentuk pertumbuhan lamun di tiap stasiunnya, sehingga karakteristik ekosistem lamun Pulau Semak Daun dapat tergambarkan dengan lebih jelas.

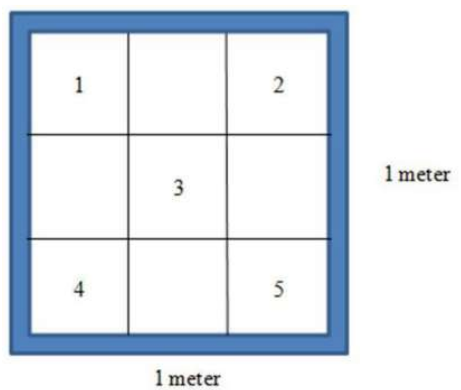

Gambar 2. Plot kerapatan lamun.

Figure 2. Seagrass density plot.

Setelah stasiun dan transek ditentukan, observasi dan indentifikasi setiap plot dilakukan untuk mendapatkan nilai kerapatan dan frekuensi kemuculannya. Jumlah individu lamun dalam tiap plot dicatat berdasarkan spesiesnya. Rumus nilai kerapatan dan frekuensi kemunculan yang digunakan adalah

- Rumus perhitungan kerapatan (Khouw dalam Graha, 2015):

$$
D_{i}=\frac{\sum n_{i}}{A_{i}}
$$

Keterangan

$\boldsymbol{D}_{\boldsymbol{i}}: \begin{aligned} & \text { kerapatan } \\ & \left(\text { tunas } / \mathrm{m}^{2} \text { ) }\right.\end{aligned}$

$\sum \boldsymbol{n}_{\boldsymbol{i}}$ : jumlah tunas lamun spesies ke i 
$\boldsymbol{A}_{\boldsymbol{i}} \quad$ : jumlah luas subplot yang memiliki lamun spesies ke i $\left(\mathrm{m}^{2}\right)$

- Rumus perhitungan frekuensi kemunculan (Khouw dalam Graha, 2015):

Keterangan

$$
F_{i}=\frac{\sum t_{i}}{T} x 100 \%
$$

$\boldsymbol{F}_{\boldsymbol{i}} \quad$ : frekuensi spesies ke i (\%)

$\sum \boldsymbol{t}_{\boldsymbol{i}}$ : jumlah subplot yang memiliki lamun spesies ke i

$\boldsymbol{T} \quad$ : jumlah total subplot yang digunakan

Pengambilan sampel dilakukan kepada empat spesies lamun paling banyak tumbuh di Pulau Semak Daun dengan jumlah lima tunas (shoot/individu) pada tiap spesiesnya. Penyimpanan sampel dilakukan dengan cara mendinginkan sampel hingga $\leq 4^{\circ} \mathrm{C}$. Sampel dibawa ke laboratorium dalam kondisi dingin untuk mencegah terjadinya dekomposisi biomassa.

\section{Pengukuran Stok Karbon}

Setiap tunas sampel akan dibersihkan dari epifit dan dibagi menjadi dua bagian yaitu Abg dan Blg. Setelah itu, sampel dipisahkan berdasarkan spesies dan lokasinya. Kemudian sampel dikeringkan pada suhu $60^{\circ} \mathrm{C}$ selama 72 jam menggunakan oven untuk mendapatkan nilai biomasa lamun. Stok karbon dihitung dengan metode pengabuan dengan memasukkan sampel ke dalam oven selama 3 jam pada suhu $300^{\circ} \mathrm{C}$ untuk mendapatkan berat abunya, kemudian dikombinasikan dengan nilai kerapatan untuk mendapatkan nilai stok karbon area.

Dalam menghitung stok karbon, diperlukan nilai biomassa dalam satuan area tertentu. Nilai biomassa dikalikan dengan nilai kandungan karbon organik dari lamun untuk menghitung stok karbon. Rumus perhitungan biomassa yang digunakan:

- Biomassa Area (Graha, 2015)

$$
B K_{\text {area }}=B K_{i} x D_{i}
$$

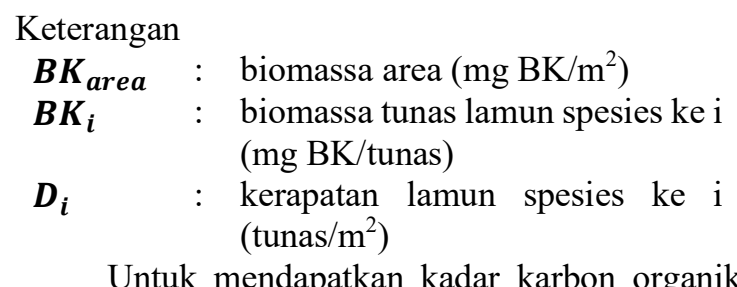
pada lamun dilakukan metode pengabuan berdasarkan Helrick dalam Graha (2015) and Howard et al. (2014). Dengan rumus:
- Persen TOM (Persen Materi Organik) (Indriani et al., 2017)

$$
\% \text { TOM }=\frac{b-a}{b} x 100 \%
$$

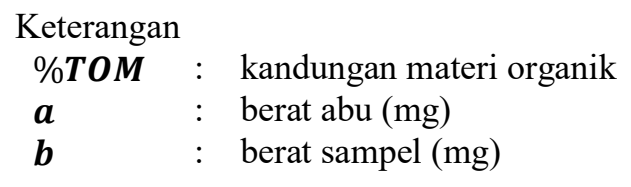

- Kandungan Karbon Organik (Helrich dalam Indriani et al., 2017)

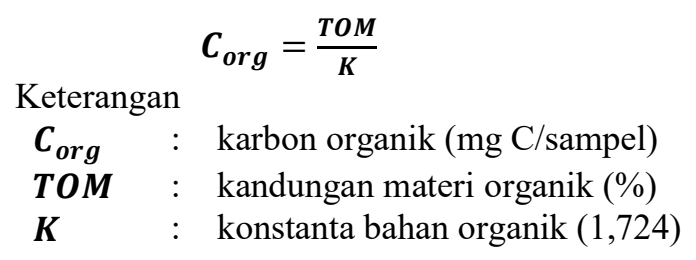

\section{Pengukuran Kualitas Air}

Pengukuran kualitas air dilakukan secara in situ pada tiap stasiun saat pengamatan untuk mengetahui keadaan lingkungan pada saat pengambilan sampel. Parameter fisika yang diukur adalah suhu dan kecerahan dengan menggunakan termometer (Balance, 1996) dan secchi disk. Parameter kimia yang diukur adalah salinitas dan pH dengan menggunakan refraktometer (Ohrel \& Register, 2006) dan $\mathrm{pH}$ meter (Balance, 1996).

\section{Penentuan Luas Padang Lamun}

Dalam menentukan luas padang lamun di Pulau Semak Daun, digunakan alat GPS untuk merekam lokasi padang lamun dan software GIS untuk membantu menghitung luasannya. Geotagging dilakukan di sekeliling padang lamun di Pulau Semak Daun. Sistem koordinat yang digunakan dalam perhitungan adalah WGS 1984 (Dana, 1994).

\section{Analisis Statistika}

Analisis stasistika dilakukan dengan bantuan aplikasi SPSS 17.0. Uji statistik yang dilakukan adalah uji komparatif Two Way ANOVA yang sebelumnya telah didahului dengan uji normalitas Shapiro-Wilk. Uji komparatif dilakukan untuk melihat apakah ada perbedaan yang signifikan antara stok karbon dari tiap spesies lamun. Data yang digunakan adalah nilai stok karbon/individu dari masing-masing sampel lamun. 


\section{Hasil}

\section{Kondisi Umum Ekosistem Lamun}

Berdasarkan hasil penelitian yang telah dilakukan, ditemukan lima spesies lamun yang tumbuh di perairan Pulau Semak Daun, yaitu $H$. ovalis, T. hemprichii, C. rotundata, Syringodium isoetifolium, dan $H$. uninervis. Kelima spesies lamun tersebar di sekeliling Pulau Semak Daun hingga $240 \mathrm{~m}$ dari bibir pantai. Luas ekosistem lamun yang terukur di pesisir Pulau Semak Daun seluas 9,1 ha (Gambar 1). Substrat dari ekosistem lamun Pulau Semak Daun adalah pasir kasar. Hasil pengukuran kualitas air pesisir Pulau Semak Daun menunjukkan bahwa terdapat dua parameter yang tidak sesuai dengan baku mutu, yaitu suhu dan salinitas, sedangkan parameter kecerahan dan $\mathrm{pH}$ berada pada kondisi optimum (Tabel 1).

Tabel 1. Hasil pengukuran kualitas air. Table 1. Water quality measurement results.

\begin{tabular}{lll}
\hline Parameter & Station 1 & Station 2 \\
\hline Physics & & \\
Transparency & $100 \%$ & $100 \%$ \\
Temperature & $33{ }^{\circ} \mathrm{C}$ & $33^{\circ} \mathrm{C}$ \\
\hline Chemistry & & \\
Salinity & $25,1 \% 0$ & $25 \% 0$ \\
pH & 8,45 & 8,45 \\
\hline
\end{tabular}

\section{Frekuensi Kemunculan}

T. hemprichii merupakan spesies lamun dengan frekuensi kemunculan tertinggi di lokasi penelitian (Gambar 3) yang menunjukkan bahwa spesies lamun ini banyak ditemukan di perairan Pulau Semak Daun. Spesies lamun dengan persentase frekuensi kemunculan terendah adalah S. isoetifolium dan C. rotundata yaitu $16,13 \%$. Persebaran S. isoetifolium lebih banyak di bagian timur, sedangkan $C$. rotundata berpusat pada bagian Barat stasiun 1 dan pada jarak $\leq 40 \mathrm{~m}$ dari bibir pantai Pulau Semak Daun.

\section{Kerapatan dan Biomassa Lamun}

Nilai kerapatan lamun menunjukkan jumlah individu lamun dalam suatu area tertentu. Nilai kerapatan lamun dari Pulau Semak Daun dapat dilihat pada Gambar 4. Kerapatan lamun rata-rata Pulau Semak Daun berkisar adalah 375 individu $/ \mathrm{m}^{2}$ yang tergolong kategori sangat rapat menurut Braun-Blanquet dalam Gosari \& Haris (2012).

Perbedaan berat kering (BK) lamun antara bagian atas substrat dan bagian bawah substrat adalah seperti Tabel 2. Rata-rata biomassa bagian atas substrat dari lamun $H$. uninervis, $T$. hemprichii, S. isoetifolium, dan $C$. rotundata adalah $66,86 \mathrm{mg}$ BK/individu, sedangkan bagian bawah substratnya sebesar 73,68 mg BK/individu.

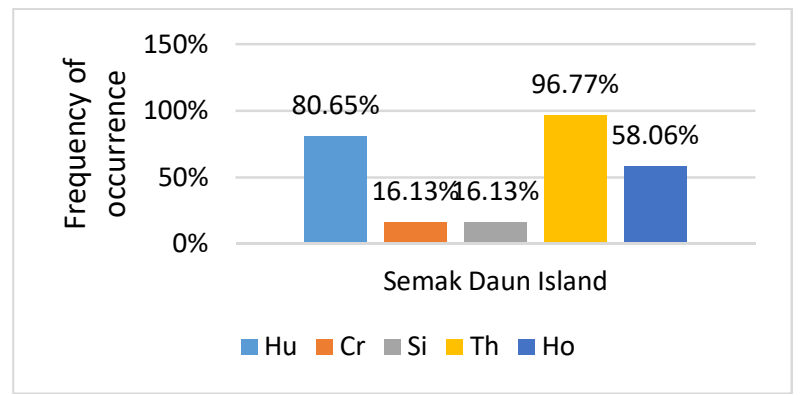

Gambar 3. Frekuensi kemunculan lamun Pulau Semak Daun.

Figure 3. Seagrass occurrence frequency at Semak Daun Island.

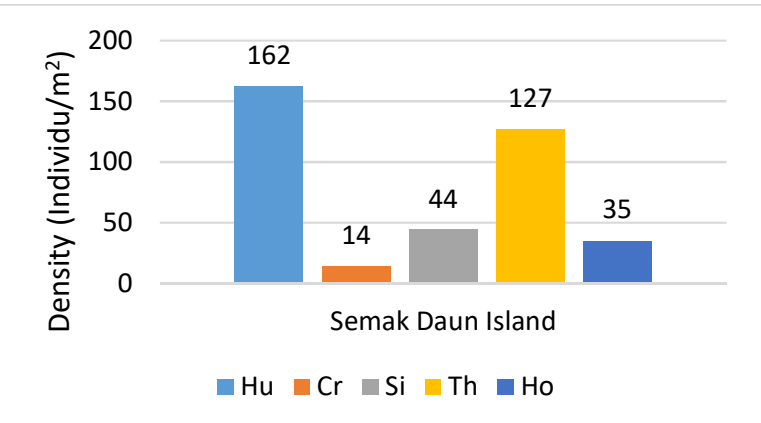

Gambar 4. Kerapatan lamun Pulau Semak Daun. Figure 4. Seagrass density at Semak Daun Island.

Tabel 2. Rata-rata biomassa lamun bagian atas dan bawah substrat.

Table 2. Aboveground (Abg) and belowground (Blg) seagrass biomass average.

\begin{tabular}{ccc}
\hline $\begin{array}{c}\text { Seagrass } \\
\text { Species }\end{array}$ & $\begin{array}{c}\text { Abg Biomass } \\
\text { (mg dw } \\
\text { /shoot) }\end{array}$ & $\begin{array}{c}\text { Blg } \\
\text { Biomass } \\
\text { (mg dw } \\
\text { /shoot) }\end{array}$ \\
\hline H. uninervis & 116.42 & 59.06 \\
T. hemprichii & 102.02 & 177.387 \\
S. isoetifolium & 16.21 & 15.6 \\
C. rotundata & 32.78 & 42.66 \\
\hline
\end{tabular}

Stok Karbon Biomassa Lamun

Simpanan karbon lebih banyak tersimpan pada bagian bawah substrat (Tabel 3). Walaupun beberapa spesies lamun seperti $H$. uninervis dan $S$. isoetifolium memiliki nilai biomassa bagian atas substrat yang lebih besar, namun kandungan karbon terbanyak tetap tersimpan pada bagian bawah substratnya. Keadaan ini sesuai dengan penelitian dari Graha (2015) yang menyatakan bahwa stok karbon bagian bawah substrat 
berkontribusi sebesar $60 \%$ dan stok karbon bagian atas substrat sebesar $40 \%$. Persentase simpanan karbon bagian bawah substrat adalah 52\% dari keseluruhan biomassa individu, sedangkan simpanan karbon bagian atas substratnya 48\%. Persentase stok karbon bagian bawah substrat dipengaruhi oleh ukuran dari rizoma dan akar lamun, sedangkan stok karbon bagian atas substrat dipengaruhi ukuran daun dan batangnya (Duarte \& Chiscano dalam Sarfika, 2012).

Berdasarkan Tabel 3, stok karbon tertinggi dimiliki oleh T. hemprichii dan stok karbon terendah dimiliki oleh C. rotundata. Selain itu, frekuensi kemunculan $\mathrm{T}$. hemprichii di Pulau Semak Daun sebesar 96,77\% yang berarti lamun jenis ini tumbuh menyebar di sekeliling pulau. Enam puluh persen dari total stok karbon Pulau Semak Daun disumbangkan oleh T. hemprichii.
Stok karbon dari keseluruhan spesies lamun adalah sebesar $20.257,48 \mathrm{mg} \mathrm{C} / \mathrm{m}^{2}$. Dengan luas lamun perairan Pulau Semak Daun sebesar 9,1 ha, maka stok karbon total Pulau Semak Daun adalah 1,843 t C (Gambar 5) atau setara dengan 6,76 $\mathrm{t} \mathrm{CO}_{2}$ (Nellemann et al., 2009).

Simpanan/stok karbon antarspesies lamun berbeda signifikan (Two Way ANOVA, sig., $p=$ 0.008). Secara khusus, T. hemprichii memiliki perbedaan simpanan karbon yang signifikan dibandingkan dengan $S$. isoetifolium (Two Way ANOVA compartive test, $p=0.010$ ). Sementara itu perbandingan simpanan karbon antarspesies yang lain tidak menunjukkan perbedaan yang signifikan. Perbedaan stasiun juga memberikan pengaruh terhadap perbedaan signifikan terhadap simpanan karbon (Two Way ANOVA, sig., $p=0.025$ ).

Tabel 3. Stok karbon bagian atas dan bagian bawah substrat serta stok karbon area lamun. Table 3. Carbon stock of seagrass area, aboveground and belowground.

\begin{tabular}{|c|c|c|c|c|c|}
\hline $\begin{array}{l}\text { Seagrass } \\
\text { Species }\end{array}$ & Biomass & Station 1 & Station 2 & $\begin{array}{l}\text { Carbon Stock } \\
\left(\mathrm{mg} \mathrm{C} / \mathbf{m}^{2}\right)\end{array}$ & $\begin{array}{l}\text { Total Carbon } \\
\text { Stock (t C)* }\end{array}$ \\
\hline \multirow{2}{*}{ H. uninervis } & $\begin{array}{l}\text { Abg carbon (mg } \\
\mathrm{C} / \mathrm{mg} \mathrm{dw})\end{array}$ & 0.28931 & 0.31272 & \multirow{2}{*}{7106,86} & \multirow{2}{*}{0,646} \\
\hline & $\begin{array}{l}\text { Blg carbon (mg } \\
\mathrm{C} / \mathrm{mg} \mathrm{dw})\end{array}$ & 0.31253 & 0.35247 & & \\
\hline \multirow{2}{*}{ T. hemprichii } & $\begin{array}{l}\text { Abg carbon (mg } \\
\mathrm{C} / \mathrm{mg} \mathrm{dw})\end{array}$ & 0.32530 & 0.32713 & \multirow{2}{*}{12136,22} & \multirow{2}{*}{1,104} \\
\hline & $\begin{array}{l}\text { Blg carbon (mg } \\
\text { C/mg dw) }\end{array}$ & 0.34133 & 0.35390 & & \\
\hline \multirow{2}{*}{ S. isoetifolium } & $\begin{array}{l}\text { Abg carbon (mg } \\
\mathrm{C} / \mathrm{mg} \mathrm{dw})\end{array}$ & 0.29766 & 0.30058 & \multirow{2}{*}{290,51} & \multirow{2}{*}{0,026} \\
\hline & $\begin{array}{l}\text { Blg carbon (mg } \\
\mathrm{C} / \mathrm{mg} \mathrm{dw})\end{array}$ & 0.31092 & 0.32570 & & \\
\hline \multirow{2}{*}{ C. rotundata } & $\begin{array}{l}\text { Abg carbon (mg } \\
\mathrm{C} / \mathrm{mg} \mathrm{dw})\end{array}$ & 0.31117 & - & \multirow{2}{*}{195,93} & \multirow{2}{*}{0,018} \\
\hline & $\begin{array}{l}\text { Blg carbon (mg } \\
\mathrm{C} / \mathrm{mg} \mathrm{dw})\end{array}$ & 0.33825 & - & & \\
\hline \multicolumn{4}{|c|}{ Seagrass ecosystem } & 20257,48 & 1,843 \\
\hline
\end{tabular}

* Seagrass area 9,1 ha. 


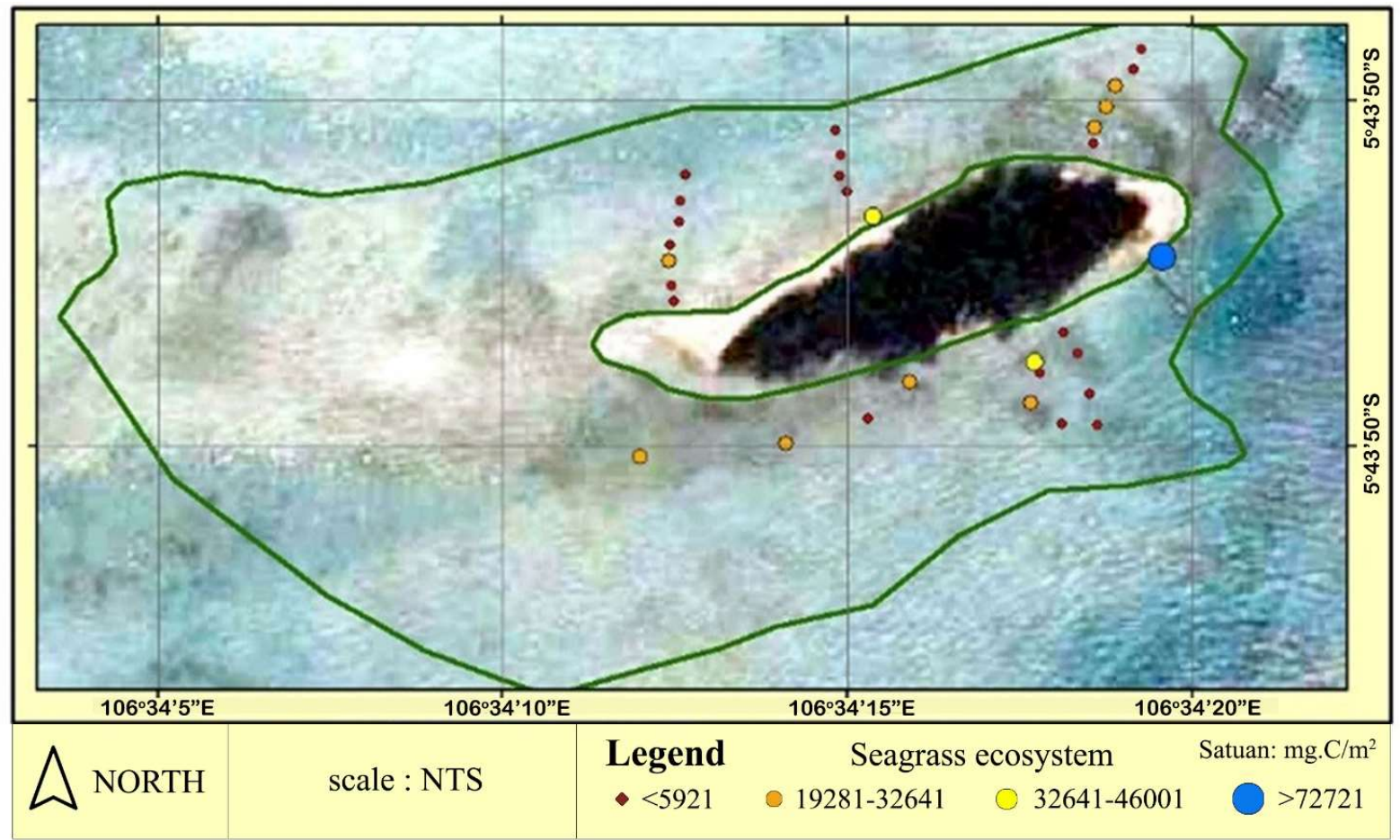

Note: Basic map from @2018 Google Earth Pro, density classification by Barun Blanquet dalam Gosari \& Haris (2012).

Gambar 5. Peta distribusi stok karbon lamun Pulau Semak Daun.

Figure 5. Seagrass carbon stock distribution map at Semak Daun Island.

\section{Pembahasan}

Padang lamun Pulau Semak Daun bervegetasi campuran dengan spesies lamun yang memiliki kerapatan tertinggi adalah $H$. uninervis. Adapun lamun $T$. hemprichii memiliki distribusi yang luas di Pulau Semak Daun namun $S$. isoetifolium, $H$. ovalis, dan $C$. rotunda tumbuh bercampur dengan $T$. hemprichii dan $H$. uninervis dalam jumlah sedikit.

Lamun di Pulau Semak Daun memiliki ukuran yang bervariasi sesuai dengan lokasi pertumbuhannya. Contohnya lamun $H$. uninervis dapat tumbuh hingga memiliki biomassa sebesar $265,03 \mathrm{~g} \mathrm{BK} / \mathrm{m}^{2}$ pada plot 1 stasiun 2, sedangkan rata-rata biomassanya adalah $21,38 \mathrm{~g} \mathrm{BK} / \mathrm{m}^{2}$. Pertumbuhan lamun pada plot 1 stasiun 2 dapat tumbuh dengan subur diduga karena lokasi pertumbuhan yang dekat dengan jeti, sehingga lamun mendapatkan perlindungan dari arus. Pada lokasi lain seperti stasiun 1, biomassa lamun lebih kecil karena lokasinya yang tidak terlindung (Patty \& Rifai, 2013) serta koloni pertumbuhannya yang bercampur dengan lamun spesies lain. Menurut Sarfika (2012), lamun yang tumbuh pada habitat yang padat akan memiliki pertumbuhan yang lebih lambat. Menurut Kiswara dalam Feryatun et al.
(2012), kerapatan lamun dipengaruhi beberapa faktor lingkungan, yaitu kedalaman, kecerahan, arus dan tipe substrat.

\section{Hubungan antara Morfologi Spesies dan Kondisi Habitat dengan Stok Karbon Padang Lamun}

Berdasarkan hasil perhitungan, kandungan karbon lamun sebesar $30-34 \%$ dari berat keringnya, dengan persentase rata-ratanya $33 \%$. Persentase ini sesuai dengan pernyataan dari Howard et al. (2014) yang menyatakan bahwa kandungan karbon di lamun sebesar 34\% dari berat keringnya. Di Pulau Semak Daun, kandungan ratarata karbon lamun sebesar 0,644 mg C/mg BK.

Berdasarkan nilai frekuensi kemunculan, kerapatan dan total stok karbon tiap spesies lamun, dapat diketahui bahwa banyaknya stok karbon dipengaruhi oleh kerapatan lamun dan juga biomassa lamun. C. rotundata memiliki stok karbon total yang rendah karena jumlahnya yang sedikit dan lokasi pertumbuhannya yang jarang dan ukuran daun, batang dan akarnya lebih kecil. $T$. hemprichii memiliki stok karbon yang tinggi karena jumlahnya yang banyak dan lokasi pertumbuhan yang menyebar serta ukuran daun, batang dan akar yang lebih besar dan tebal. 
Berdasarkan hasil uji statistik Two Way ANOVA, ditemukan perbedaan rata-rata simpanan karbon antarspesies lamun dan antarstasiun Pulau Semak Daun. Secara statistika, terdapat perbedaan yang nyata antara simpanan karbon perberat kering $T$. hemprichii terhadap S. isoetifolium maupun sebaliknya. Rata-rata simpanan karbon perberat kering dari spesies lainnya tidak memberikan perbedaan yang nyata baik terhadap $T$. hemprichii maupun terhadap $S$. isoetifolium. Perbedaan yang signifikan ini diduga akibat perbedaan morfologi yang besar antara lamun $T$. hemprichii yang memiliki daun yang lebar dan rizoma yang tebal dengan lamun $S$. isoetifolium yang memiliki daun yang tipis dan rizoma yang kecil (Iswari et al., 2017). Selain itu, ditemukan hasil bahwa ada perbedaan simpanan karbon lamun perberat kering yang signifikan antara stasiun 1 dan stasiun 2 . Diduga perbedaan simpanan karbon dapat terjadi karena adanya perbedaan keadaan lingkungan yang mendukung pertumbuhan lamun (Fajarwati et al., 2015). Stasiun 1 memiliki morfologi pantai lebih landai dengan kedalaman hanya $50 \mathrm{~cm}$, sedangkan stasiun 2 memiliki morfologi pantai yang lebih curam dengan kedalaman $170 \mathrm{~cm}$.

Pulau Semak Daun memiliki stok karbon yang lebih rendah dibandingkan dengan Pulau Pramuka dan Pulau Pari yaitu sebesar 1,843 t C (Tabel 4). Rendahnya stok karbon ini diduga dipengaruhi oleh luas ekosistem lamun, kerapatan, juga spesies lamun yang tumbuh, dan juga aktivitas antropogenik di sekitar ekosistem. Luas ekosistem lamun Pulau Semak Daun lebih rendah dibandingkan dengan Pulau Pramuka dan Pulau Pari (Rahmawati, 2011; Iwari, 2013). Menurut McKenzie et al. (2007) luasan ekosistem lamun di suatu perairan dipengaruhi oleh beberapa faktor, yaitu faktor fisik (suhu, salinitas, ombak, arus, kedalaman, substrat, dan lama penyinaran), faktor alam (cahaya, nutrisi, epifit, dan penyakit), dan faktor antropogenik (limbah dan sediment). Kerapatan dipengaruhi oleh faktor kedalaman, kecerahan, arus dan tipe substrat (Kiswara dalam Feryatun et al., 2012), sedangkan spesies lamun yang tumbuh memengaruhi nilai biomassa lamunnya. Aktivitas pariwisata di ekosistem lamun berpotensi menurunkan stok karbon dari ekosistem lamun itu sendiri. Menurut Travaille et al. (2015) dan Eckrich \& Holmquist (2000), kegiatan wisata yang menyebabkan terinjak-injaknya lamun mengakibatkan penurunan kerapatan lamun. Limbah dari kegiatan pariwisata juga dapat menyebabkan penurunan kualitas air.

Sementara itu, Pulau Pari memiliki ekosistem lamun yang bertipe vegetasi campuran dan juga sejenis. Menurut Kiswara dalam Minerva et al. (2014), kerapatan ekosistem lamun juga dipengaruhi oleh morfologi lamun yang tumbuh. Jika lamun yang tumbuh berukuran besar seperti $E$. acoroides, maka jumlah tunas yang tumbuh dalam suatu area akan lebih sedikit. Namun, jika lamun yang tumbuh berukuran kecil, maka jumlah tunas yang tumbuh pada area tersebut dapat berjumlah lebih banyak (Kiswara, 2010). Substrat dasar Pulau Pari yang terdiri dari pasir dengan sedikit lumpur (Saogo, 2016) dan kedalaman yang berkisar antara 0,44-1,2 m (Kusumaatmaja et al., 2016) mendukung untuk pertumbuhan lamun $E$. acoroides (Mustono 2016; Sahertian \& Wakano 2017). Banyaknya lamun E. acoroides yang tumbuh menyebabkan biomassa rata-rata ekosistem lamun Pulau Pari memiliki nilai yang tinggi.

Pulau Pramuka memiliki ekosistem lamun yang bertipe vegetasi campuran. Substrat dasar Pulau Pramuka terdiri dari pasir, lumpur dan pecahan karang dengan kedalaman berkisar antara 0,7-1,35 m (Fajarwati et al., 2015). Dengan keadaan ekosistem tersebut, spesies lamun yang dominan di Pulau Pramuka adalah T. hemprichii, $C$. rotundata, dan $C$. serrulate. Jenis lamun yang tumbuh di Pulau Pramuka dan Pulau Semak Daun tidak berbeda jauh, sehingga rata-rata biomassa keduanya juga tidak berbeda jauh.

Jumlah stok karbon dari ekosistem lamun menunjukan nilai banyaknya $\mathrm{CO}_{2}$ yang dapat diserap oleh ekosistem tersebut. Semakin besar nilai stok karbon dari suatu ekosistem akan semakin baik, karena memberikan kontribusi besar dalam proses mitigasi perubahan iklim. Menurut Howard et al. (2014), ekosistem lamun memiliki kemampuan yang baik dalam menyimpan karbon. Ekosistem lamun dapat menyimpan karbon dalam waktu yang lebih lama dibandingkan ekosistem terestrial. Oleh karena itu, pengelolaan wilayah pesisir untuk menjaga ekosistem lamun sangat diperlukan, sehingga penyerapan $\mathrm{CO}_{2}$ oleh ekosistem lamun dapat meningkat. Peningkatan penyerapan $\mathrm{CO}_{2}$ dari atmosfer sangat diperlukan untuk mengurangi dampak pemanasan global. 
Oseanologi dan Limnologi di Indonesia 2019 4(2):89-99

Tabel 4. Stok karbon Pulau Semak Daun, Pulau Pramuka dan Pulau Pari.

Table 4. Carbon stock at Semak Daun Island, Pramuka Island and Pari Island.

\begin{tabular}{cccc}
\hline Parameter & $\begin{array}{c}\text { Semak Daun } \\
\text { Island }\end{array}$ & Pramuka Island & Pari Island \\
\hline Density (shoot/m) & 375 & $666,2^{[\mathrm{C}]}$ & $308-399^{[\mathrm{E}]}$ \\
\hline $\begin{array}{c}\text { Seagrass ecosystem } \\
\text { area (ha) }\end{array}$ & 9,1 & $59,25^{[\mathrm{D}]}$ & $32,71^{[\mathrm{B}]}$ \\
\hline Biomass (g dw/m & & $83^{[\mathrm{A}]}$ & $486^{[\mathrm{F}]}$ \\
\hline $\begin{array}{c}\text { Carbon stock average } \\
\left(\mathbf{g ~ C} / \mathbf{m}^{2}\right)\end{array}$ & 59,5 & $200,90^{[\mathrm{D}]}$ & $200,5^{[\mathrm{F}]}$ \\
\hline $\begin{array}{c}\text { Total carbon stock (t } \\
\text { C) }\end{array}$ & 1,843 & $119,03^{[\mathrm{D}]}$ & $67,21^{[\mathrm{F}]}$ \\
\hline
\end{tabular}

Sources: ${ }^{[\mathrm{A}]}$ Assuyuti et al. (2016); ${ }^{[\mathrm{B}]}$ Rahmawati (2011); ${ }^{[\mathrm{C}]}$ Fajarwati et al. (2015); ${ }^{[\mathrm{D}]}$ Iwari (2013); ${ }^{[\mathrm{E}]}$

Kusumaatmaja et al. (2016); and ${ }^{[\mathrm{F}]}$ Rahmawati (2011).

\section{Kesimpulan}

Spesies lamun yang ditemukan di Pulau Semak Daun terdiri dari lima spesies, yaitu $H$. ovalis, $T$. hemprichii, C. rotundata, $S$. isoetifolium, dan $H$. uninervis. Luas ekosistem lamun sebesar 9,1 ha, dengan total stok karbon dari lamun $T$. hemprichii, H. uninervis, $S$. isoetifolium, dan $C$. rotundata secara berurutan adalah $1,104 \mathrm{t} \mathrm{C}, 0,646$ t C, 0,026 t C, dan 0,018 t C. Stok karbon total ekosistem lamun Pulau Semak Daun adalah 1,843 t C.

\section{Ucapan Terimakasih}

Terimakasih penulis ucapkan kepada Taman Nasional Laut Kepulauan Seribu Pulau Pramuka dan Laboratorium Biogeokimia, Pusat Penelitian Oseanografi LIPI serta staf laboratorium yang membantu dalam proses penelitian. Penulis JVG, MP, AJW, dan FZ mendesain riset dan sampling desain. Penulis JVG menuliskan draf awal dan penulis lainnya memberikan masukan, menyempurnakan informasi dan sistematika penyusunan jurnal. Semua penulis telah membaca dan menyetujui manuskrip dengan JVG sebagai penanggung jawab korespondensi.

\section{Daftar Pustaka}

Assuyuti, Y. M., Rijaluddin, A. F., Ramadhan, F., \& Zikrillah, R. B. (2016). Estimasi Jumlah Biomassa Lamun di Pulau Pramuka, Karya dan Kotok Besar, Kepulauan Seribu, Jakarta. Depik, 5(2), 85-93.

Ballance, R. (1996). Field Testing Methods. In J. Bartram, \& R. Ballance, Water Quality Monitoring - A Practical Guide to the Design and Implementation of Freshwater Quality Studies and Monitoring Programmes (pp. 93-110). Great Britain:
United Nations Environment Programme. Diakses dari https://apps.who.int/iris/bitstream/handle/10 665/41851/0419217304_eng.pdf?sequence $=1 \&$ isAllowed $=\mathrm{y}$.

BPLH (Badan Pengelola Lingkungan Hidup) Daerah Provinsi DKI Jakarta. (2010). Status Lingkungan Hidup Daerah Provinsi Daerah Khusus Ibukota Jakarta. Jakarta: Pemerintah Provinsi DKI Jakarta. Diakses dari

http://perpustakaan.bappenas.go.id/lontar/fil e?file=digital/124697-[_Konten_]Konten\%20C8620.pdf

BPLH (Badan Pengelola Lingkungan Hidup) Daerah Provinsi DKI Jakarta. (2015). SD20. Luas dan Kerusakan Padang Lamun. Diakses dari Status Lingkungan Hidup Daerah Provinsi Daerah Khusus Ibukota Jakarta:

https://lingkunganhidup.jakarta.go.id/Docs/ Data/bab_1/SD-20.html

Dana, P. H. (1994, Juli 9). UTM Zone Numbers. Diakses dari MapRef.org: http://mapref.org/UTMProjectionSystem.html

Eckrich, C. E., \& Holmquist, J. G. (2000). Trampling in a Seagrass Assemblage: Direct Effects, Response of Associated Fauna, and The Role of Substrate Characteristics. Marine Ecology Progress Series 201, 199 209.

Fajarwati, S. D., Setianingsih, A. I., \& Muzani. (2015). Analisis Kondisi Lamun (Seagrass) di Perairan Pulau Pramuka, Kepulauan Seribu. SPATIAL Wahana Komunikasi dan Informasi Geografi, 3(1), 22-32.

Feryatun, F., Hendrarto, B., \& Widyorini, N. (2012). Kerapatan dan Distribusi Lamun (Seagrass) Berdasarkan Zona Kegiatan yang Berbeda di Perairan Pulau Pramuka, 
Kepulauan Seribu. Journal of Management of Aquatic Resources, 1-7.

Gosari, B. A., \& Haris, A. (2012). Studi Kerapatan dan Penutupan Jenis Lamun di Kepulauan Spermonde. Torani, 22(3), 156-162.

Graha, Y. I. (2015). Simpanan Karbon Padang Lamun di Kawasan Pantai Sanur, Kota Denpasar (Tesis). Denpasar: Universitas Udayana.

Howard, J., Hoyt, S., Isensee, K., Pidgeon, E., \& Telszewski, M. (2014). Coastal Blue Carbon: Methods for Assessing Carbon Stocks and Emissions Factors in Mangroves, Tidal Salt Marshes, and Seagrass Meadows. Arlington, Virginia, USA: Conservation International, Intergovernmental Oceanographic Commission of UNESCO, International Union for Conservation of Nature.

Indriani, Wahyudi, A. J., \& Yona, D. (2017). Cadangan Karbon di Area Padang Lamun Pesisir Pulau Bintan, Kepulauan Riau. Oseanologi dan Limnologi di Indonesia 3(2), 1-11.

Iswari, M. Y., Hernawan, U. E., Sjafrie, N. D., Supriyadi, I. H., Suyarso, Anggraini, K., \& Rahmat. (2017). Album Peta Lamun. Jakarta: COREMAP-CTI, Pusat Penelitian Oseanografi-LIPI.

Iwari, F. A. (2013). Laju Penyerapan dan Kandungan Karbon pada Komunitas Lamun di Pulau Pramuka, Kepulauan Seribu, DKI Jakarta. Jakarta: Universitas Indonesia.

Kiswara, W. (2010, November 16). Studi Pendahuluan: Potensi Padang Lamun sebagai Karbon Rosot dan Penyerap karbon di Pulau Pari, Teluk Jakarta. Diakses dari Loka Pengembangan Kompetensi Sumber Daya Manusia Oseanografi: http://file.pksdmo.lipi.go.id/id018-5fee02650 215.pdf

Kusumaatmaja, K. P., Rudiyanti, S., \& Ain, C. (2016). Hubungan Perbedaan Kerapatan Lamun dengan Kelimpahan Epifauna di Pantai Lipi Pulau Pari Kepulauan Seribu. Diponegoro Journal of Maquares, 5(4), 398-405.

McKenzie, L., Yaakub, S. M., \& Yoshida, R. (2007). Seagrass-Watch: Guidelines for Team Seagrass Singapore Participants. Proceedings of training workshop, National Parks Board, Biodiversity Centre (p. 32pp). Singapore: DPI\&F, Caims.

Minerva, A., Purwanti, F., \& Suryanto, A. (2014). Analisis Hubungan Keberadaan dan Kelimpahan Lamun dengan Kualitas Air di
Pulau Karimunjawa, Jepara. Diponegoro Journal of Maquares 3(3), 88-94.

Muliawaty, A. D., Herawati, T., \& Lili, W. (2012). Struktur Komunitas Perifiton dan Hubungannya dengan Kerapatan Lamun di Pulau Semak Daun, Kepulauan Seribu. Bandung: Universitas Padjadjaran. Diakses dari http://fpik.unpad.ac.id/strukturkomunitas-perifiton-dan-hubungannyadengan-kerapatan-lamun-di-pulau-semakdaun-kepulauan-seribu/

Mustono. (2016). Prediksi Model Perubahan Zonasi Spesies Lamun Berdasarkan Variasi Kedalaman sebagai Isu Kenaikan Muka Air Laut di Pulau Barrang Lompo Kepulauan Spermonde Kota Makassar. Makasar: Universitas Hasanuddin.

NASA (National Aeronautics and Space Administration) GISS (Goddard Institute for Space Studies). (2018). Global Temperature. Diakses dari NASA Global Climate Change: https://climate.nasa.gov/vital-signs/globaltemperature/

Nellemann, C., Corcoran, E., Duarte, C. M., Valdés, L., Young, C. D., Fonseca, L., \& Grimsditch, G. (2009). Blue Carbon: A Rapid Response Assessment. Norwey: United Nations Environment Programme, GRID-Arendal.

Ohrel, J. R., \& Register, K. M. (2006). Salinity. In J. R. Ohrel, \& K. M. Register, Volunteer Estuary Monitoring, A Methods Manual, Second Edition (pp. 14:1-8). U.S: The Ocean Conservancy, Environmental Protection Agency.

Patty, S. I., \& Rifai, H. (2013). Struktur Komunitas Padang Lamun di Perairan Pulau Mentehage, Sulawesi Utara. Jurnal Ilmiah Platax, 1(4), 177-186.

Putuhena, J. D. (2011). Perubahan Iklim dan Resiko Bencana pada Wilayah Pesisir dan Pulau-Pulau Kecil. Seminar Nasional Pengembangan Pulau-Pulau Kecil dari Aspek Perikanan Kelautan dan Pertanian (pp. 287-298). Bogor: Institut Pertanian Bogor.

Rahmawati, S. (2011). Estimasi Cadangan Karbon pada Komunitas Lamun di Pulau Pari, Taman Nasional Kepulauan Seribu, Jakarta. Jurnal Segara 7(1), 1-12.

Sahertian, D. Elisabeth, \& Wakano, D. (2017). Laju Pertumbuhan Daun Enhalus acoroides pada Substrat Berbeda di Perairan Pantai Desa Poka Pulau Ambon. Jurnal Biology Science \& Education, 6(1), 62-68. 
Oseanologi dan Limnologi di Indonesia 2019 4(2):89-99

Saogo, D. Y. (2016). Struktur dan Sebaran Meiofauna pada Ekosistem Lamun di Peraiaran Pulau pari, Kepulauan Seribu. Bogor: Institut Pertanian Bogor.

Sarfika, M. (2012). Pertumbuhan dan Produksi Lamun Cymodocea rotundata dan Cymodocea serrulata di Pulau Pramuka dan
Pulau Panggang, Kepulauan Seribu, DKI Jakarta. 2012: Institut Pertanian Bogor. Travaille, K., Salinas-de-Leon, P., \& Bell, J. (2015). Indication of Visitor Trampling Impacts on Intertidal Seagrass Beds in a New Zealand Marine Reserve. Ocean \& Coastal Management 114, 145-150. 